\title{
HYDROCHEMICAL AND BIOLOGICAL CHARACTERISTICS OF THREE HIGH ALTITUDINAL TROPICAL RESERVOIRS OF WESTERN GHATS, SOUTH INDIA, WITH SPECIAL REFERENCE TO POTABILITY
}

\author{
Saranya. $\mathbf{P}^{1}$, Krishnakumar. A ${ }^{2}$, Anoop Krishnan. $K^{3}$ \\ ${ }^{I}$ Natural Reseources and Environmental Management Group (NREM) \\ ${ }^{2}$ ESSO-National Centre for Earth Science Studies (NCESS), \\ ${ }^{3}$ Ministry of Earth Sciences (MoES), Government of India
}

\begin{abstract}
Western Ghats, being one of the biological hot spots, has always been critical for a host of natural resources, particularly for water and biodiversity, and thus serves as an important bio-geo-asset. A number of reservoirs are located in Western Ghats in and around the catchment areas of various rivers. Reservoirs are extremely important due to the role they play in generating hydroelectric power, fish production, irrigation and as a source of drinking water. Physico-chemical characteristics of water and its relationship to the diversity of phytoplanktons, were studied in three major reservoirs of Western Ghats; namely Mullaperiyar Dam, Gavi Dam and Pamba Dam. 18 species falling in 3 divisions of phytoplanktons were found. The greatest number of species were noted in division Chlorophyceae followed by Bacillariophyceae (Diatoms). The abundance of diatoms was well explained by the higher loading of silicates (77.92, 81.02, and 74.2 $\mathrm{mg} / \mathrm{l}$ ) while other nutrients were very low in the reservoir waters. Chlorophyll contents of the respective reservoirs were very low $(0.18,0.014$ and $0.167 \mathrm{mg} / \mathrm{l})$ indicating the oligotrophic nature of reservoirs and justified by the low nutrient status (Nitrite $=B D L$ in all reservoirs, Phosphate $=0.091$ $\mathrm{mg} / \mathrm{l}, 0.567 \mathrm{mg} / \mathrm{l}, 0.299 \mathrm{mg} / \mathrm{l}$ and Sulphate 78.9mg/l, $111.1 \mathrm{mg} / \mathrm{l}, 98.1 \mathrm{mg} / \mathrm{l}$ in Mullaperiyar, Gavi and Pamba Dams respectively). Water qualities of reservoir waters were assessed against the drinking standards and found that silicate content and E.coli counts were high in all reservoirs. The presence of phytoplanktons tolerant to organic pollution were identified using Palmer's diversity index and the pollution status of the reservoir waters were estimated using Shannon and Weaver's diversity index.
\end{abstract}

Keywords: Reservoirs, Water Quality, Phytoplanktons

\section{INTRODUCTION}

Western Ghats is a magnificent mountain range, one among the seven great mountain ranges in the country next to Himalayas and is a biological treasure trove with a high degree of endemism and scenic beauty. This unique ecosystem has been threatened by continuously increasing habitat pressures and declared as one of the world's hottest hotspots of biodiversity [1]. The strategic position of Western Ghats is so apt to capture the moisture laden trade winds that blows annually, and hence causing copious rains.

Although the Kerala State is endowed with abundant rainfall, the unique geographical characteristics of the State make it difficult to achieve the target of providing safe drinking water to all. Further, the decay of natural water bodies impedes water conservation in the State. The condition is again worsened by inefficient management of water, over extraction of surface and groundwater as well as pollution resulting from waste disposal. It has been reported that the per capita availability of water in Kerala is less than that of the arid and semi arid zones in India. A general assumption cannot be drawn that the condition is pathetic all over the State, but some specific regions and pockets demand immediate attention. It therefore becomes important to develop location specific sustainable water projects. Hence, the role of reservoirs became predominant for meeting the future water demands of the State. The Western Ghats have several natural and manmade lakes and reservoirs. Kerala State has 53 reservoirs spread over ten districts. Yet, only a few reservoirs have been utilized for providing drinking water for the State and it becomes important to study the potability of water in the other reservoirs for meeting the future water demands. This paper deals with the hydrochemical and biological quality of three selected reservoirs of Western Ghats namely Mullaperiyar, Gavi and Pamba with special reference to potability. In 2013, Ministry of Environment and Forests (MoEF), Government of India demarcated the Ecologically Sensitive Areas (ESA) in Western Ghats and the present study areas falls in ESAs.

Phytoplanktons are used as indicators of water quality as they can tolerate wide range of pollution in the aquatic environment and are considered as the index of trophic status, since they reflect the overall environmental condition of the system and its potentiality [2 \& 3]. They are mainly 
responsible for net as well as gross primary productivity of the system and are the source of base level energy in food webs maintaining in the water bodies. Distribution of phytoplanktons and their variation at different zones of water body is known to be influenced by physico-chemical parameters of water [4]. Qualitative and quantitative analysis of different groups of organisms have led to the establishment of bio-indicators, indices and systems that can be used for the assessment of pollution and trophic status of water bodies. Palmer (1969) [5] made the first attempt to identify and prepare a list of 60 genera and 80 species of algae tolerant to organic pollution.

Phytoplankton ecology is of special importance in the study of science of reservoirs as they play a dynamic role in trapping solar energy and also reflect the average ecological condition [6]. Presently, bio-monitoring and indices have become an essential part of water quality and pollution studies [7]. Although many studies have been carried out on different aspects of reservoirs in midland regions of the State, studies on the reservoirs of high altitudinal areas of Western Ghats are still lacking. Hence, an attempt is made to provide a valuable database on phytoplanktons and water quality of the three high altitudinal reservoirs viz: Mullaperiyar, Gavi and Pamba of Western Ghats located in Kerala State.

\section{STUDY AREA}

Western Ghats or Sahyadri is a mountain range that runs almost parallel to the western coast of the Indian Peninsula. These high altitude ranges are considered as ecologically sensitive and were not well explored in scientific regards. The three selected reservoirs of this study viz; Mullaperiyar, Gavi and Pamba are among the most important reservoirs of Kerala State. These reservoirs serve as the major sources of water for meeting the irrigational, drinking and hydroelectric demands of Kerala and Tamil Nadu States (Fig. 1).

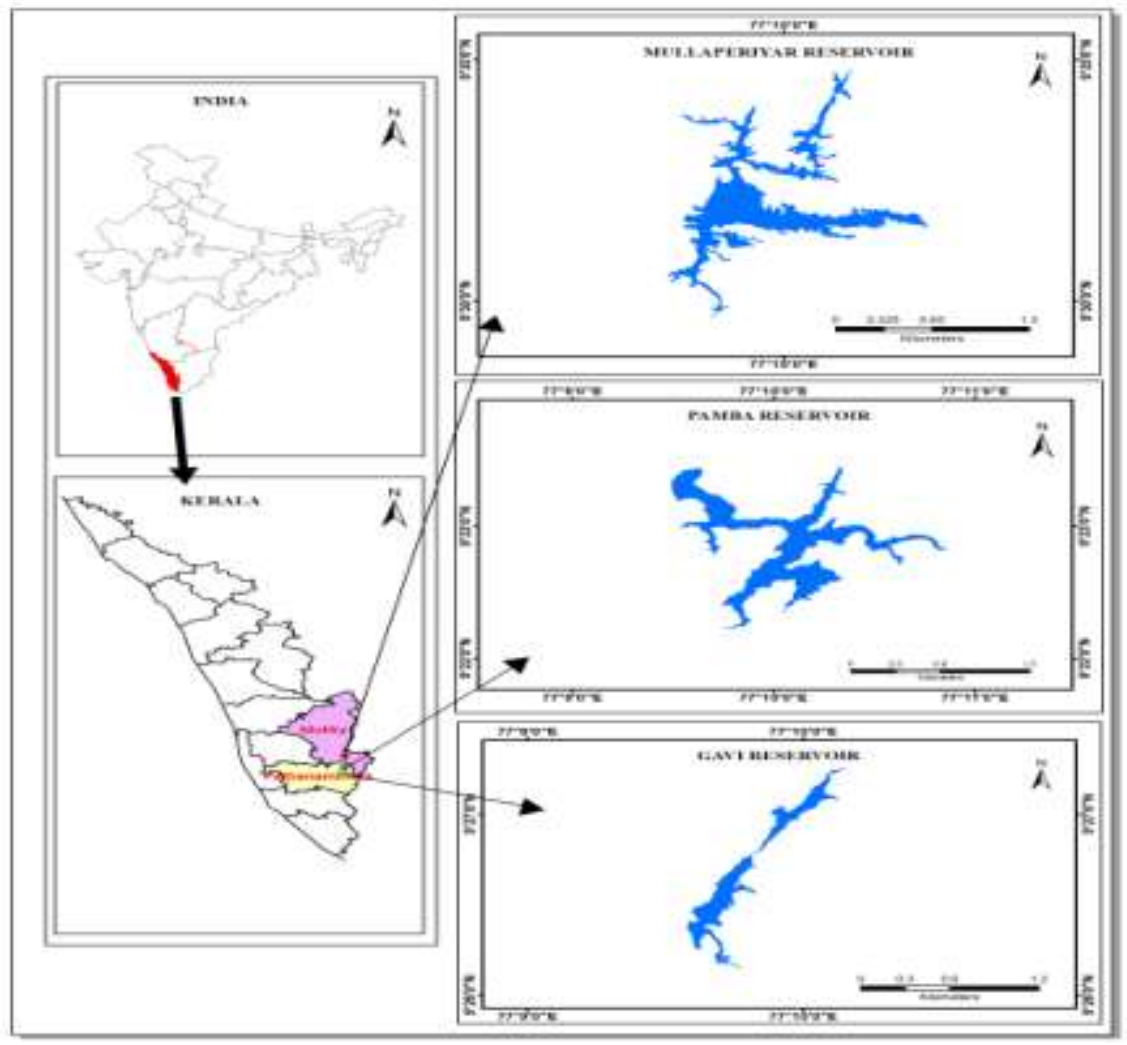

Fig 1 Map showing the study areas

Mullapperiyar Reservoir is a masonry gravity dam located $881 \mathrm{~m}$ above mean sea level between $9^{0} 31^{\prime} 43^{\prime \prime} \mathrm{N}$ latitudes and $77^{\circ} 08^{\prime} 53^{\prime \prime}$ in. As the dam is located in the convergence zone of the Mullayar and Periyar rivers, it is called Mullaperiyar. Although the 116-year-old dam is located in Kerala, it is operated by the Government of Tamil Nadu. The capacity of the reservoir is $15662 \mathrm{~m}^{3}$, and the water is used for irrigation, drinking and generation of power in Lower Periyar Power Station. The diverted water of Periyar river through Mullaperiyar dam is used for various needs of the people of Tamil Nadu State as well. Gavi Reservoir is a gravity dam located between $9^{0} 26^{\prime} 20^{\prime \prime} \mathrm{N}$ latitudes and $77^{0}$ 10' 11" E longitudes across Pamba river. The dam was being built for hydroelectric needs. The dam has a height of 17.07 $\mathrm{m}$ and a length of $97.54 \mathrm{~m}$. Presently, the reservoir is also used for recreational purposes as part of ecotourism development. Pamba Reservoir is located between $9^{0} 22^{\prime} 52^{\prime \prime}$ $\mathrm{N}$ latitudes and $77^{0} 10^{\prime} 05^{\prime \prime} \mathrm{E}$ longitudes Pamba river. The reservoir has a height of $57.2 \mathrm{~m}$ and length of $281 \mathrm{~m}$, built for hydroelectric and irrigation needs,. 


\section{MATERIALS AND METHODS}

\subsection{Sample Collection and Identification}

Surface water samples were collected from the reservoirs for quality analysis, chlorophyll quantification and phytoplankton enumeration. Water quality determining parameters were analyzed following standard methods [8]. The phytoplankton samples were enumerated up to the lowest taxonomic rank with the aid of a binocular phase contrast microscope [9]. Chlorophyll 'a' content in water samples were estimated by filtering one liter of water through GF/C glass filter paper and the extraction of pigments were done with $90 \%$ acetone [10].

\subsection{H Index (Shannon-Weaver Diversity Index)}

Among the various diversity indices available, the Shannon and Weaver's diversity index was used in the study and was calculated following Shannon-Weaver (1949) [11] formula,

\section{$\mathbf{H}=\sum \mathbf{P i} \ln \mathbf{P i}$}

Where, $\mathbf{P i}=\mathbf{N i} / \mathbf{N}$, represent the portion of species in the community,

$\mathrm{Ni}=$ Number of individuals of a species I,

$\mathrm{N}=$ Total number of individuals.

Wilhm and Dorris, 1966 [12]; reported that the Shannon and Weaver's diversity index $(\mathrm{H})$ is an expression of correlation with pollution status of the ecosystem. They have suggested a relationship between species diversity and pollution status of aquatic ecosystems and classified as follows:

$>3=$ Clean water

1-3 = Moderately polluted water

$<1=$ Heavily polluted

But, Staub et al (1970) [13] proposed a modified scale of pollution that states negative correlation between organic pollution and Shannon's index (Table 1).

Table 1: Shannon and Weaver's diversity index and scale of organic pollution (Staub et al., 1970)

\begin{tabular}{|l|l|}
\hline $\begin{array}{l}\text { Shannon and Weaver's } \\
\text { diversity index }(\mathbf{H})\end{array}$ & Pollution Status \\
\hline $3.0-4.5$ & Slight pollution \\
\hline $2.0-3.0$ & Light pollution \\
\hline $1.0-2.0$ & Moderate Pollution \\
\hline $0.0-1.0$ & Heavy Pollution \\
\hline
\end{tabular}

Here, the Shannon and Weaver's diversity index proposed by Staub et al (1970) is used for discussing the results.

\section{RESULTS AND DISCUSSION}

\subsection{Water Quality}

Water quality determining parameters of the reservoirs were analyzed and the results were compared with BIS Standards (2012) for the quality assessment and presented in Table 2.

The reservoirs waters were in good agreement with drinking water quality limits for most of the parameters. The parameters like TDS, TSS, alkalinity, chloride, total hardness, calcium hardness, magnesium hardness, sodium, potassium, sulphate, nitrite, phosphate, fluoride and copper contents were very low in all three reservoirs.

Water turbidity of Gavi (8.4 NTU) and Pamba (7.83 NTU) reservoirs were above the standard limits. Biochemical Oxidation Demand (BOD), which is an indication of organic pollution, is very high in Mullaperiyar and Pamba reservoirs, where the Periyar river water drains the organic contaminants from upstream regions of the Western Ghats forests and Pamba river water is expected to drain organic pollutants from the upstream and tourism prone areas to the Pamba reservoir. Compared to other nutrients, silicates were very high in all the three reservoirs (Fig 2). The dissolution of particulate silicon carried by the river, removal of silicates by adsorption and co-precipitation of soluble silicate-silicon with humic compound and iron [14] might have contributed to this higher silicate level.

E.coli count was found high in Gavi (52 CFU/ml)) and Pamba (54 CFU/ml) reservoirs, both are fed by Pamba river, indicating the elevated levels of biological contamination while the count was nil in Mullaperiyar reservoir. As observed by Firozia et al., 2013 [15], the coliform count of the Pamba river is attributed by the Sabarimala pilgrimage because pilgrims use the river for sanitation purposes due to lack of proper sanitary arrangements, also, the holy dip by pilgrims is conducted in the river. The present study on the reservoir waters of Gavi and Pamba reservoirs reaffirms that the upstream areas of Pamba river is biologically polluted.

Table 2: Water quality assessment of Mullaperiyar, Gavi and Pamba reservoirs against the BIS standards

\begin{tabular}{|l|l|l|l|l|l|}
\hline Parameters & $\begin{array}{l}\text { Mullaperiyar } \\
\text { Reservoir }\end{array}$ & $\begin{array}{l}\text { Gavi } \\
\text { Reservoir }\end{array}$ & $\begin{array}{l}\text { Pamba } \\
\text { Reservoir }\end{array}$ & $\begin{array}{l}\text { BIS, 2012 } \\
\text { (Maximum } \\
\text { allowable) }\end{array}$ & Assessment of Water Quality \\
\hline Temperature $\left({ }^{\mathbf{0}} \mathbf{C}\right)$ & 27.2 & 25.4 & 26.5 & - & \\
\hline pH & 6.97 & 6.58 & 6.74 & $6.5-8.5$ & Good \\
\hline Conductivity $(\boldsymbol{\mu S} / \mathbf{c m})$ & 41.89 & 22.26 & 18.91 & & \\
\hline TDS $(\mathbf{m g} / \mathbf{l})$ & 43.73 & 23.11 & 20.04 & $2000 \mathrm{mg} / \mathrm{l}$ & Very Low \\
\hline
\end{tabular}




\begin{tabular}{|c|c|c|c|c|c|}
\hline TSS (mg/l) & 0.69 & 0.002 & 0.002 & & Very Low \\
\hline Turbidity (NTU) & 4.23 & 8.4 & 7.83 & $5 \mathrm{NTU}$ & $\begin{array}{l}\text { Good in Mullaperiyar reservoir, } \\
\text { above the BIS limit in other } \\
\text { two reservoirs. }\end{array}$ \\
\hline DO (mg/l) & 11.52 & 8.96 & 11.2 & - & Good \\
\hline BOD (mg/l) & 9.6 & 2.4 & 7.36 & - & $\begin{array}{l}\text { High in Mullaperiyar and } \\
\text { Pamba and low in Gavi } \\
\text { reservoir. }\end{array}$ \\
\hline Alkalinity (mg/l) & 8 & 32 & 20 & $600 \mathrm{mg} / \mathrm{l}$ & Very low \\
\hline Chloride (mg/l) & 3.1 & 3.6 & 2.1 & $1000 \mathrm{mg} / \mathrm{l}$ & Very low \\
\hline Total Hardness (mg/l) & 24 & 12 & 24 & $600 \mathrm{mg} / \mathrm{l}$ & Very low \\
\hline Calcium Hardness (mg/l) & 3.2 & 6.4 & 1.6 & $200 \mathrm{mg} / \mathrm{l}$ & Very low \\
\hline $\begin{array}{ll}\text { Magnesium } & \text { Hardness } \\
(\mathrm{mg} / \mathrm{l})\end{array}$ & 20.8 & 5.6 & 22.4 & $100 \mathrm{mg} / \mathrm{l}$ & Low \\
\hline $\mathrm{Na}(\mathrm{mg} / \mathrm{l})$ & 1.43 & 1.07 & 0.94 & $\begin{array}{l}200 \mathrm{mg} / \mathrm{l} \\
(\mathrm{WHO})\end{array}$ & Very low \\
\hline $\mathrm{K}(\mathrm{mg} / \mathrm{l})$ & 1.72 & 2.57 & 1.74 & - & - \\
\hline Sulphate (mg/l) & 0.08 & 0.11 & 0.09 & $400 \mathrm{mg} / \mathrm{l}$ & Negligible \\
\hline Nitrite $(\mathrm{mg} / \mathrm{l})$ & BDL & BDL & BDL & - & BDL \\
\hline Phosphate (mg/l) & 0.09 & 0.57 & 0.29 & - & Negligible \\
\hline Silicate (mg/l) & 77.92 & 81.02 & 74.2 & - & $\begin{array}{l}\text { High when compared with } \\
\text { other nutrients }\end{array}$ \\
\hline Fluoride $(\mu \mathrm{g} / \mathrm{l})$ & 2.41 & 2.1 & 2.2 & $1.5 \mathrm{mg} / \mathrm{l}$ & Very Low. \\
\hline E.Coli & NIL & 52 & 54 & $\mathrm{Nil} / 100 \mathrm{ml}$ & $\begin{array}{l}\text { While the E.coli count is nil in } \\
\text { Mullaperiyar; the other } \\
\text { reservoirs are severely } \\
\text { contaminated. }\end{array}$ \\
\hline Co (mg/l) & 0.04 & 0.08 & 0.08 & - & - \\
\hline $\mathrm{Cu}(\mathrm{mg} / \mathrm{l})$ & 0 & 0 & 0 & $1.5 \mathrm{mg} / \mathrm{l}$ & Not contaminated \\
\hline
\end{tabular}

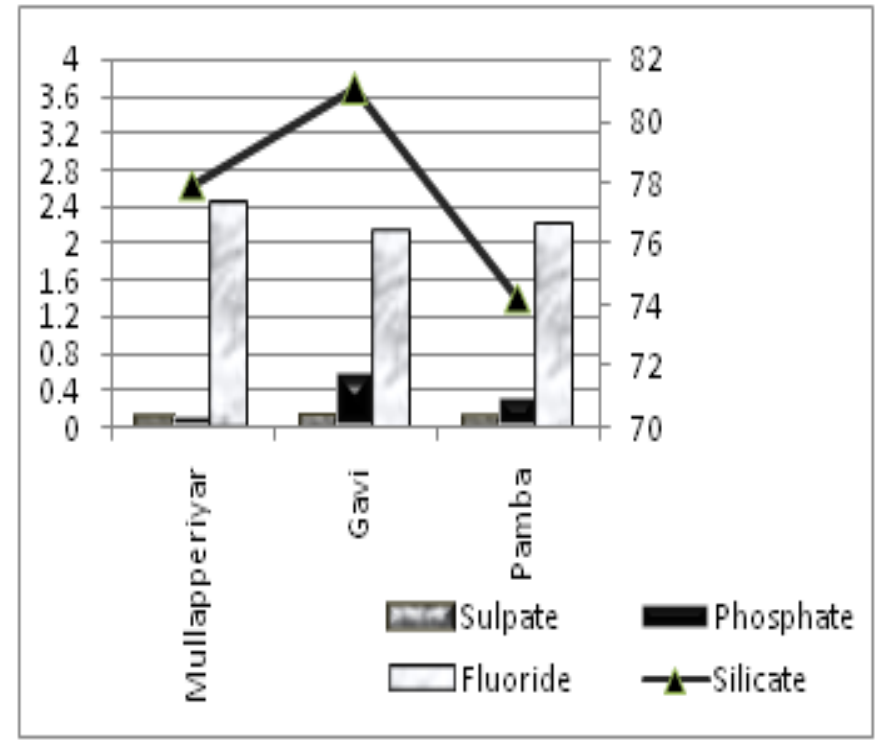

Fig 2: Nutrient levels in Mullaperiyar, Gavi and Pamba reservoirs (Sulphate, Phosphate and Silicates are expressed in $\mathrm{mg} / \mathrm{l}$ and Fluoride in $\mu \mathrm{g} / \mathrm{l}$ )

\subsection{Phytoplanktons}

The various phytoplankton species identified in the reservoir waters were listed in Table 3 and its distribution is presented in Fig 3. The microscopic images of some dominant phytoplankton species were presented in Fig 4.

\subsubsection{Mullaperiyar Reservoir}

Two major groups of phytoplanktons comprising of ten genera were identified in Mullaperiyar reservoir (6 of Chlorophyceae and 4 of Bacillariophyceae). Out of the 3120 cells/litre (cells/l), Bacillariophyceae dominated the reservoir with 1800 cells/l which is about $58 \%$ of the phytoplankton count. Aulacoseria sp. (Bacillariophyceae) was the most dominant genera with about $42 \%$ of species followed by Staurastrum sp. (Chlorophyceae). Among the phytoplanktons identified, 2 genera fall in the list of pollution tolerant algal genera identified by Palmer (1969). Cosmarium and Pinnularia are the two species found tolerant to organic pollution in the reservoir waters. 


\subsubsection{Gavi Reservoir}

In Gavi reservoir, Chlorophyceae and Diatoms were the major phytoplanktons identified. Of these, with $81 \%$ composition, Chlorophyceae dominated the reservoir with 6 genera. Among the different genera, Staurastrum was the most dominant genera comprising about $21 \%$ with 1680 cells/l.

The genera Melosira, Pediastrum and Scenedesmus found in Gavi reservoir fall in Palmer's list of algal species tolerant to organic pollution.

\subsubsection{Pamba Reservoir}

Chlorophyceae and Diatoms were the phytoplankton groups identified in Pamba reservoir; among these, Diatoms dominated with $52 \%$ of composition. Nitzschia longissima was the most dominant species in the reservoir, contributing about $35 \%$ of the total phytoplankton composition. In Pamba reservoir, Miractinum, Asterionella, Fragileria, Nitzschia, Pediastrum and Gonium are found tolerant to organic pollution

Table 3: List of phytoplanktons identified in Mullaperiyar, Gavi and Pamba reservoirs

\begin{tabular}{|c|c|c|c|c|c|}
\hline Reservoirs & Species name & Counts (Cells/l) & $\begin{array}{l}\text { Percentage } \\
\text { composition }(\%)\end{array}$ & $\begin{array}{l}\text { Total no of } \\
\text { species }\end{array}$ & $\begin{array}{l}\text { Total counts } \\
(\text { Cells/l })\end{array}$ \\
\hline \multirow{10}{*}{ Mullaperiyar } & Cosmarium & 120 & 3.85 & \multirow{10}{*}{10} & \multirow{10}{*}{3120} \\
\hline & Chlorogonium & 120 & 3.85 & & \\
\hline & Staurastrum & 600 & 19.23 & & \\
\hline & Aulacoseira & 1320 & 42.31 & & \\
\hline & Craticula & 120 & 3.85 & & \\
\hline & Tetraedron (Sps 1) & 120 & 3.85 & & \\
\hline & Pinnularia & 240 & 7.69 & & \\
\hline & Actinastrum & 120 & 3.85 & & \\
\hline & Tetraedron (Sps II) & 240 & 7.69 & & \\
\hline & Rhizosolenia & 120 & 3.85 & & \\
\hline \multirow{8}{*}{ Gavi } & Staurastrum & 1680 & 20.59 & \multirow{8}{*}{8} & \multirow{8}{*}{8160} \\
\hline & Actinastrum & 840 & 10.29 & & \\
\hline & Tetraedron & 2040 & 25 & & \\
\hline & Melosira & 240 & 2.94 & & \\
\hline & Langerheimia & 120 & 1.47 & & \\
\hline & Pediastrum & 480 & 5.88 & & \\
\hline & Scenedesmus & 1440 & 17.65 & & \\
\hline & Aulacoseira & 1320 & 16.18 & & \\
\hline \multirow{8}{*}{ Pamba } & Aulacoseira & 1080 & 13.04 & \multirow{8}{*}{8} & \multirow{8}{*}{8280} \\
\hline & Micractinum & 2160 & 26.09 & & \\
\hline & Asterionella & 240 & 2.9 & & \\
\hline & Fragileria & 120 & 1.45 & & \\
\hline & Nitzschia & 2880 & 34.78 & & \\
\hline & Pediastrum & 360 & 4.35 & & \\
\hline & Gonium & 120 & 1.45 & & \\
\hline & Tetraedron & 1320 & 15.94 & & \\
\hline
\end{tabular}

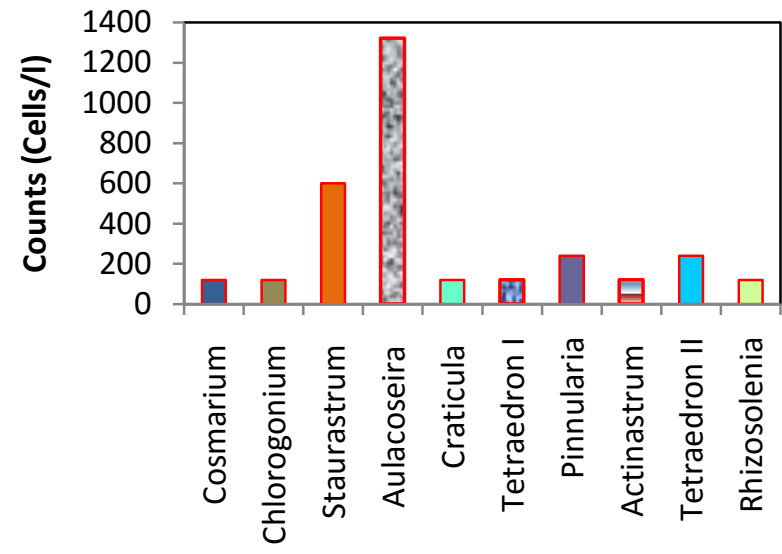

A

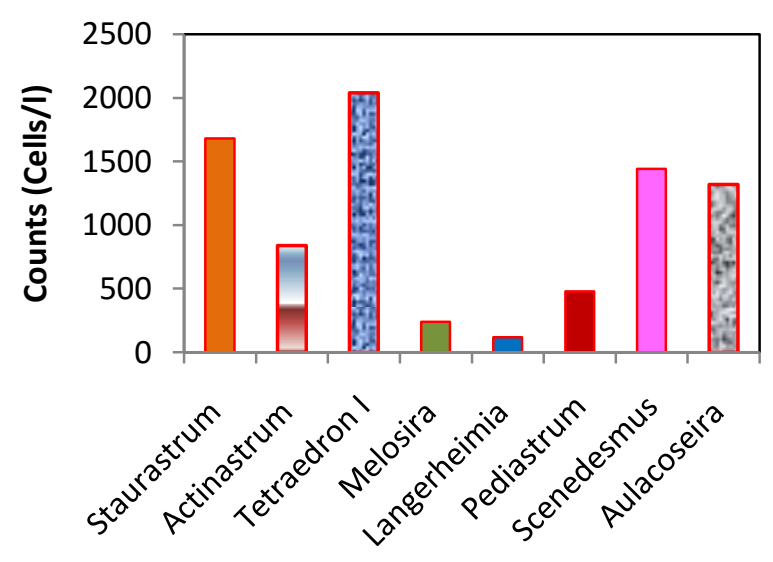

B 


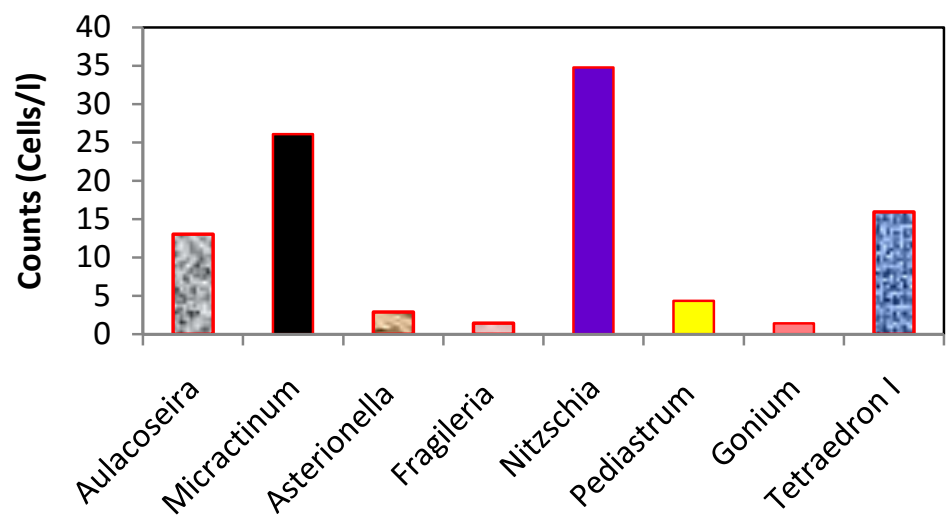

C

Fig 3: Phytoplankton diversity in the Reservoir Waters A- Mullaperiyar, B- Gavi and C- Pamba)

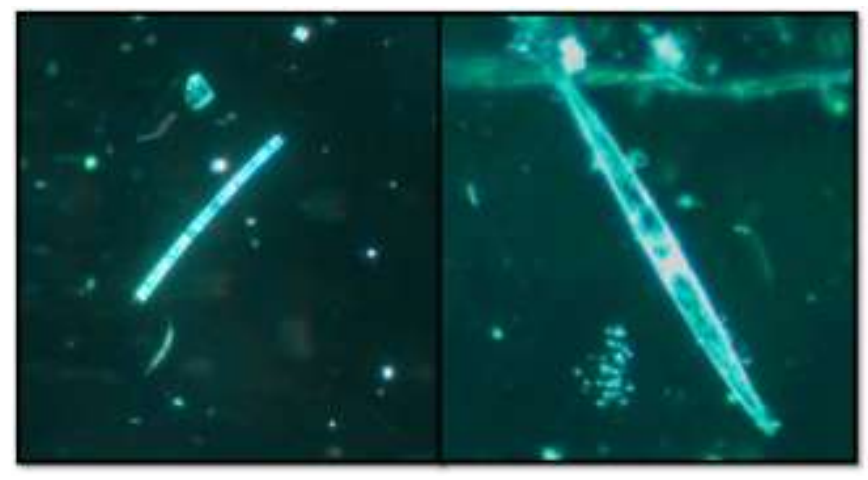

A

B

Fig 4: Microscopic images of Aulacoseria sp (A) and Nitzschia sp (B) in the reservoir waters.

\subsubsection{Shannon- Weaver's Diversity Index}

According to the Shannon and Weaver's diversity index; $\mathrm{H}$ index values in the range of 1-2 indicate moderate level of pollution and less diversity of organisms. Since, the present reservoirs are located in relatively undisturbed areas of the Western Ghats; nutrients that accelerate the growth and diversity of phytoplanktons are very less. The obtained moderate pollution index value is very much depend upon higher levels of BOD in Mullaperiyar and Pamba reservoirs; on the other hand, higher E.coli count in Gavi and Pamba reservoirs.

Table 4: Shannon and Weaver's diversity index and pollution status of reservoirs

\begin{tabular}{|l|l|l|}
\hline Reservoir Name & Values & \multirow{2}{*}{ Pollution Status } \\
\hline Mullaperiyar & 1.83 & \multirow{2}{*}{ Moderate } \\
\hline Gavi & 1.84 & \\
\hline Pamba & 1.68 & \\
\hline
\end{tabular}

\subsection{Chlorophyll Productivity}

Chlorophyll a values are the measurements of phytoplankton density in general and the extent of eutrophication as well [16]. The chlorophyll a values were $0.18 \mu \mathrm{g} / \mathrm{l}$ in Mullapperiyar reservoir, $0.014 \mu \mathrm{g} / \mathrm{l}$ in Gavi reservoir and
$0.167 \mu \mathrm{g} / \mathrm{l}$ in Pamba reservoir. As per the Organisation for Economic Cooperation and Development (OECD) [17] classification of trophic state, chlorophyll a content below 2.5 $\mu \mathrm{g} / \mathrm{l}$ shows oligotrophic condition of water bodies. Lower levels of nutrients with limited diversity of phytoplanktons also reiterate the oligotrophic nature of reservoirs.

\section{SUMMARY AND CONCLUSION}

Kerala's annual average rainfall figures give a misleading picture about water availability on real terms. The dry weather flow in all Rivers of the State has been dwindling at an alarming rate affecting the water sector as a whole, major casualty being the drinking water sector. Source reliability is critical to the sustainability of drinking water supply schemes and the reduction in run off together with sand mining, salinity intrusion and solid and liquid waste discharge are putting severe pressure on the river sources. A potential solution to the source problem is to integrate drinking water supply schemes with the reservoirs in the now used for hydroelectric and irrigational purposes Western Ghats. Generally, reservoirs have several advantages as drinking water sources, with assured quantity and consistent quality. In this context, three important reservoirs of Western Ghats have been examined in detail with special reference to drinking water potential. 
Regarding potability of the reservoir waters, most of the parameters were satisfying the limits set by Bureau of Indian Standards (BIS). Among the nutrients, Silicates were dominant in all the three reservoirs while all other nutrients were scanty. The presence of E.coli in Gavi and Pamba reservoirs shed light on to the fecal contamination in Periyar river and deserves much attention. Diatoms dominated in the Mullapperiyar and Pamba reservoirs attributed to the considerable silicate availability in the reservoir waters. The Shannon and Weaver's diversity index shows low diversity of phtoplanktons in all reservoirs and indicating a moderate level of pollution. It is concluded that these high altitudinal reservoirs started facing the problem of organic pollution and its impact is visible from the presence of pollution tolerating phytoplanktons and less overall diversity; and hence proper management measures have to be taken in order to maintain the quality of the pristine reservoirs of Western Ghats, owing to their significance in the environmental setting of the State.

\section{ACKNOWLEDGEMENT}

This study has been carried out as part of MOES- NREM Core Project on 'Indian River Basin Dynamics'. The authors are thankful to Dr. Ajayakumar Varma, Group Head, NREM and Director, NCESS for constant encouragement and support.

\section{REFERENCES}

[1]. MoEF. Report of the high level working group on Western Ghats. 2013.

[2]. Agarwal SC. Limnology. A.P.H. Publishing Corporation, New Delhi, 1999.

[3]. Agarwal AK, Rozar, GR. Physico-chemical and microbiological study of Tehri deam reservoir, Garhwal Himalaya, India. Journal of American Science, 2010, pp. 6.

[4]. Ambili Nath, Neethu RV, Revathy JS. Diversity of plankton in a village pond at Dhanuvachapuram, Trivandrum. International Journal of Innovative Research in Science, Engineering and Technology, 2015, pp. 9189-9193.

[5]. Mohamed Nasser KM, Sureshkumar S. Seasonal variation and biodiversity of phytoplanktons in Parambikulam reservoir, Western Ghats, India. International Journal of Pure and Applied Bioscience, 2014, pp. 272- 280.

[6]. Palmer CM 1969. A composite rating of algae tolerating organic pollution, 1969.

[7]. Kotut, Kiplagat, Lothar Krienitz, Francis M, Muthuri. Temporal changes in phytoplankton structure and composition at the Turkwel Gorge Reservoir, Kenya. Hydrobiologia, 1998, pp. 41-59.

[8]. Pramila Kumari, Sharda Dhadse, Chaudhari PR, Wate SR. A biomonitoring of plankton to assess quality of water in the lakes of Nagpur city. Proceedings of Taal 2007: The $12^{\text {th }}$ World Lake Conference, 2008, pp. 160-164.

[9]. APHA: Standard methods for the examination of water and waste water. 22 Edn., Washington DC, USA, 2012.

[10]. Tomas, CR. Identifying marine phytoplankton. Academic Press, IC Harcowt Brace and Company, California, USA, 1997, pp. 220-480.
[11]. Santhanam R, Ramanathan N, Venkataramanujan K, Jagatheesan G. Phytoplankton of the Indian Seas, an aspect of Marine Botany, Daya Publication House, 1987, pp. 110-174.

[12]. Shannon CE, Weaver W. The Mathematical Theory of Communication.University of Illinois Press, Urbana, IL, USA, 1949.

[13]. Wilhm JL, Dorris, TC. Species diversity of benthic macroinvertebrates in a stream receiving domestic and oil refinery effluents. Amn. Midl. Nat. pp. 427-449.

[14]. Staub R, Appling JW, Hofsteiler AM, Hess IJ. The effect of industrial waste of Memphis and Shelby country on primary plankton producers. Biosciences, 1970, pp $905-912$. [15]. Rajasegar M. Physico-chemical characteristic of the vellar estuary in relation to shrimp farming. Journal of Environmental Biology, 2003, pp. 95-101.

[16]. Firozia Naseema Jalal, Sanal Kumar MG. Water quality assessment of Pamba river of Kerala, India in relation to pilgrimage season. International Journal of Research in Chemistry and Environment, 2013, pp. 341-347.

[17]. Ratheesh Kumar M, Raj Vishnu S, Sudhanandh VS, Faisal AK, Shibu R, Vimexen V, Ajmal K, Aneesh KS, Sibin Antony, Anoop Krishnan. Proliferation of dinoflagellates in Kochi estuary, Kerala. Journal of Environmental Biology, 2014, pp. 877-82. 